\title{
Seasonal variation in species richness and abundance of waterbirds in Mole National Park, Ghana: Implication for conservation and ecotourism
}

\begin{tabular}{|c|c|}
\hline \multicolumn{2}{|c|}{$\begin{array}{l}\text { Authors: } \\
\text { Timothy K. Aikins }{ }^{1,2} \\
\text { Francis Gbogbo } 10 \\
\text { Erasmus H. Owusu }\end{array}$} \\
\hline \multicolumn{2}{|c|}{$\begin{array}{l}\text { Affiliations: } \\
{ }^{1} \text { Department of } \\
\text { Animal Biology and } \\
\text { Conservation Science, } \\
\text { University of Ghana, Ghana }\end{array}$} \\
\hline \multicolumn{2}{|c|}{$\begin{array}{l}{ }^{2} \text { Department of Biodiversity } \\
\text { Conservation and } \\
\text { Management, University for } \\
\text { Development Studies, Ghana }\end{array}$} \\
\hline \multicolumn{2}{|c|}{$\begin{array}{l}\text { Corresponding author: } \\
\text { Timothy Aikins, } \\
\text { aikinskhan@live.com }\end{array}$} \\
\hline \multicolumn{2}{|c|}{$\begin{array}{l}\text { Received: } 15 \text { Mar. } 2017 \\
\text { Accepted: } 16 \text { May } 2018 \\
\text { Published: } 02 \text { Oct. } 2018\end{array}$} \\
\hline \multicolumn{2}{|c|}{$\begin{array}{l}\text { How to cite this article: } \\
\text { Aikins, T.K., Gbogbo, F. \& } \\
\text { Owusu, E.H., 2018, 'Seasonal } \\
\text { variation in species richness } \\
\text { and abundance of waterbirds } \\
\text { in Mole National Park, Ghana: } \\
\text { Implication for conservation } \\
\text { and ecotourism', Koedoe 60(1), } \\
\text { a1466. https://doi.org/ } \\
\text { 10.4102/koedoe.v60i1.1466 }\end{array}$} \\
\hline \multicolumn{2}{|c|}{$\begin{array}{l}\text { Copyright: } \\
\text { (c) 2018. The Authors. } \\
\text { Licensee: AOSIS. This wo } \\
\text { is licensed under the } \\
\text { Creative Commons } \\
\text { Attribution License. }\end{array}$} \\
\hline \multicolumn{2}{|l|}{ Read online: } \\
\hline 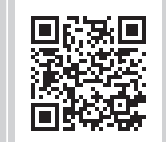 & $\begin{array}{l}\text { Scan this QR } \\
\text { code with your } \\
\text { smart phone or } \\
\text { mobile device } \\
\text { to read online. }\end{array}$ \\
\hline
\end{tabular}

Mole National Park is the largest and the oldest national park in Ghana and an important bird area, yet its waterbird fauna is poorly documented because it is situated in the northern ecological zone far away from the coast of Ghana. Information on the seasonal variation in the park's bird abundance and diversity is generally patchy but necessary for effective birdwatching planning and management of the park's birds. Therefore, as a guide to potential ecotourists interested in waterbirds, this study described the seasonal variation in waterbird species diversity and abundance at Mole National Park. As waterbirds mostly congregate around open wetlands and their abundance is more appropriately determined by counting all individuals in the congregant, data were collected using the total area count of waterbirds from August 2015 to October 2015 (the wet season) and from December 2015 to February 2016 (the dry season). Secondary data on arrival of tourists in the park were also analysed. The park's waterbird species richness was 29 in the dry season compared to 18 in the wet season. There was significant difference $(p<0.05)$ in the abundance of waterbirds in the dry season in which 4014 waterbirds were encountered compared to 646 in the wet season. The yearly tourist arrival data at Mole National Park shows an increasing trend with peak visitation period occurring during the wet season. The chances of tourists encountering more species and numbers of waterbirds in the park are higher in the dry season compared to the wet season.

Conservation implications: Species richness and abundance of waterbirds in Mole National Park varied according to the wet and dry seasons with both the number of species and abundance higher in the dry season than the wet season. It is therefore indicative that most birdwatchers who visit the park in the wet season miss out on a number of species and numbers of waterbirds. To achieve effective birdwatching, management should schedule birdwatching activities to coincide with the dry season as the chances of encountering more species and numbers of waterbirds are higher.

\section{Introduction}

Although several studies on waterbird ecology have been conducted in West Africa because of the region's importance as wintering habitat for Palearctic migrant waterbirds (Gbogbo \& Attuquayefio 2010; Gbogbo et al. 2013; Gbogbo, Yeboah \& Billah 2014; Ntiamoa-Baidu et al. 1998; Ntiamoa-Baidu, Nyame \& Nuoh 2000), the studies are largely restricted to the coastal ecological zone in the south. Scientific studies on the ecology, diversity and abundance of waterbirds in the northern ecological zone of Ghana are rare. In Ghana, for instance, the only notable works previously conducted in the northern ecological zone of Ghana include Greig-Smith $(1976,1977)$, Dowsett-Lemaire and Dowsett (2005), Obodai and Nsor (2009), Nsor and Obodai (2014) and Aikins, Ziblim and Tuga (2017). Although these studies established some baseline data on birds and assessed environmental determinants influencing seasonal diversity and abundance of birds, none of the studies focused solely on waterbirds.

Mole National Park is in the northern ecological zone of Ghana. It is the oldest and largest national park in Ghana and home for over 93 mammal species (Riley \& Riley 2005) and 33 reptile species (Briggs 2007; Riley \& Riley 2005) and about 344 species of birds (Dowsett-Lemaire \& Dowsett 2005). Despite the high diversity of bird species in the park, information on its waterbird species is generally patchy. The paucity of scientific information on the ecology of waterbirds in the northern ecological zone makes it impossible to determine the current state of the waterbirds in this zone.

Two seasons generally exist in the northern ecological zone of Ghana, namely the dry season (November to April) and the wet season (May to October) (Kuuder 2012). These seasonal 
weather variations can change water quality parameters in an area which in turn will change habitat variables, such as vegetation. Changes in vegetation characteristics will affect the availability of important food resources (Naugle et al. 2001; Riffell Keas \& Burton 2001) to waterbirds which in turn will affect their diversity and abundance. Aynalem and Bekele (2008) recorded more species of birds in the dry season as compared to the wet season at the southern tip of Lake Tana, Ethiopia. That notwithstanding, Behrouzi-Rad (2009) argued that in situations where the water dries up completely, waterbird species diversity and abundance will be lower in the dry season as compared to the wet periods. The migration of birds in response to seasonal changes is also known to affect the species richness and abundance of birds as observed by Rajashekara and Venkatesha (2014) where higher numbers of waterbird species were recorded in winter compared to other seasons because of the arrival of migratory waterbirds. Mundava et al. (2012) argued that the gathering of waterbirds at larger permanent water bodies when the small water bodies dry out could explain the high numbers of waterbirds often seen on some wetlands in the dry season whilst the low numbers of waterbirds in the wet season could be attributed to the dispersal of waterbirds.
Mole National Park attracts a large number of tourists (Lawer, Nasiru \& Kuuder 2013). Although charismatic mega-fauna, such as elephants, remains the focus of many of these ecotourists in Mole National Park, birdwatchers are also frequently seen with about $41 \%$ of the park visitors expressing interest in birds (Kuuder, Bagson \& Aalangdong 2013). In planning a successful ecotourism trip, information on seasonal variations in the diversity and abundance of fauna is paramount to the interest of tourists so as to improve the reliability of locating animals (Kuuder et al. 2013). Thus, scientific knowledge on the seasonal variation of waterbirds species diversity and abundance at Mole National Park will appropriately guide the park's potential birdwatchers in planning their trips. Besides, knowledge on the seasonal variation in waterbird species diversity and abundance of the wetlands at Mole National Park would serve as an important management tool for the park's wetlands. This study therefore reported the variations in diversity and abundance of waterbirds in the dry and wet seasons of Mole National Park.

\section{Study area}

Mole National Park $\left(9^{\circ} 12^{\prime}-10^{\circ} 06^{\prime} \mathrm{N}, 1025^{\prime}-2^{\circ} 17^{\prime} \mathrm{W}\right)$ (Figure 1) was established in 1958 as a game reserve, and in 1971, it was

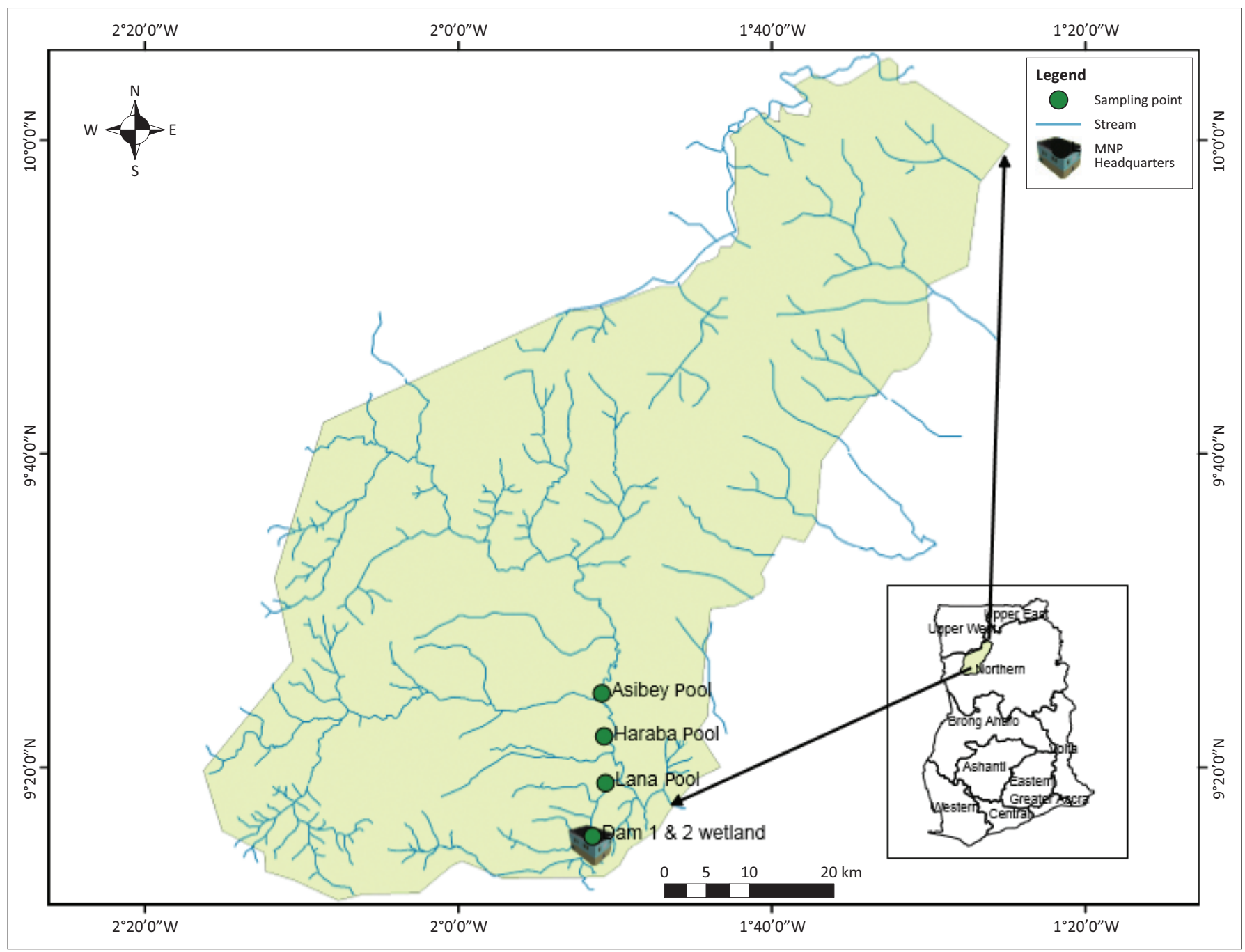

FIGURE 1: Map of Mole National Park showing the study sites. 
upgraded to a national park. A total of 344 bird species have reliably been reported to occur in Mole National Park, and this is the largest number of species reported for any conservation site in Ghana (Dowsett-Lemaire \& Dowsett 2005; NtiamoaBaidu et al. 2001). It covers an area of $4840 \mathrm{~km}^{2}$. It is located in the Guinea Savannah ecological zone with Isoberlinia doka, Butyrospermum paradoxum, Burkea africana, Combretum spp. and Terminalia avicenniodes as the common plant species. The park experiences two main seasons: the wet season (May to October) and the dry season (November to April) (Kuuder 2012). The Mole, Samole, Lovi, Zuo, Polzen and Kulpawn rivers are the major rivers that drain the park with only Polzen, Kulpawn and Mole flowing permanently; the others are reduced to stagnant pools in the dry season (Kuuder 2012). This study was based on the most important and prominent wetlands in the park that are easily accessible to the park users (Figure 1): (1) Dam 1 and 2 Wetland, (2) Lana Pool, (3) Haraba Pool and (4) Asibey Pool (Aikins, Gbogbo \& Owusu 2018).

\section{Description of study sites}

\section{Dam 1 and 2 Wetland}

Dam 1 and 2 Wetland $\left(09^{\circ} 15.576^{\prime} \mathrm{N}, 001^{\circ} 51.423^{\prime} \mathrm{W}\right)$ is about $500 \mathrm{~m}$ from the park headquarters (Aikins et al. 2018). This has no floating vegetation but is bordered by trees on one side and grassland on the other (Dowsett-Lemaire \& Dowsett 2005). This site serves as nesting grounds for birds like the Hamerkop Scopus umbretta, African Jacana Actophilornis africanus, Redthroated bee-eater Merops bullocki and several passerine birds. During the dry season, elephants use these dams as bathing ponds, and therefore, the water is always turbid.

\section{Lana Pool}

Lana Pool $\left(09^{\circ} 19.858^{\prime} \mathrm{N}, 001^{\circ} 50.383^{\prime} \mathrm{W}\right)$ is located about $9 \mathrm{~km}$ from the park headquarters and is about $3 \mathrm{~km}$ from the main access road (Aikins et al. 2018). It is the largest of the pools, and it has floating vegetation mainly on the water with trees at the banks. Buffalos (Syncerus caffer), elephants (Loxodonta africana), kobs (Kobus kob), waterbucks (Kobus ellipsiprymnus) and warthogs (Phacochoerus africanus) use this pool frequently, especially in the dry season. This pool serves as the gathering point for the White-face Whistling Duck prior to their migratory departure during the dry season.

\section{Haraba Pool}

Haraba Pool $\left(09^{\circ} 21.268^{\prime} \mathrm{N}, 001^{\circ} 50.981^{\prime} \mathrm{W}\right)$ is located about $12 \mathrm{~km}$ from the park headquarters and is about $200 \mathrm{~m}$ from the main access road (Aikins et al. 2018). It is a large circular pool with vast grassland interspersed with shrubs and trees including Combretum fragrans, Daniellia oliveri, Anogeissus leiocarpus and Piliostigma thonningii. The pool also has floating aquatic weeds such as the tropical white water lilies at certain portions of the water.

\section{Asibey Pool}

Asibey Pool $\left(09^{\circ} 22.431^{\prime} \mathrm{N}, 001^{\circ} 50.574^{\prime} \mathrm{W}\right)$ is located about $17 \mathrm{~km}$ from the park headquarters and is about $100 \mathrm{~m}$ from the main access road (Aikins et al. 2018). It is an open wetland with water that forms a permanent pool throughout the year. It has trees and shrubs such as Diospyros mespiliformis, Kigelia africana, Anogeissus leiocarpus, Morelia senegalensis and Ochna schweinfurthiana that form thickets at one side of the pool and grassland at the other side of the pool.

\section{Field work}

We obtained estimates of the abundance of the various species of waterbirds in each of the four wetlands at Mole by counting all waterbirds sighted on each wetland from the southern part of the site to the northern part. To reduce the incidence of double counting, birds in flight were not counted with the assumption that birds that fly from the southern part to the northern part of the study sites and vice versa will cancel out in the estimate of abundance (Bibby et al. 2000). Counting was performed using an $8 \times 40$ Nikon binocular. Counts were undertaken hourly between 06:00 and 09:00 and 15:00 and 18:00 over three days per month from August 2015 to October 2015 (wet season) and from December 2015 to February 2016 (dry season). This gave a total of 18 days of count per wetland except Lana and Haraba Pools that were inaccessible in the month of October 2015 because of heavy rains. Birds were identified using Borrow and Demey (2010).

\section{Secondary data}

Secondary data on tourist arrival at Mole National Park was obtained from the park and analysed for trends in the arrival of tourists. The data obtained span from 1988 to 2015. The data obtained for 1988-2012 consisted of only yearly totals. However, there was monthly data for 2012-2015 although there were some missing data on some of the months for the years 2013-2015. Therefore, the analysis of the monthly data was based on the years 2012 and 2015 only.

\section{Data analysis}

The list of waterbirds at Mole National Park was generated by pulling together all the species recorded for all the study sites. The total number of birds counted for each hour was summed and the average calculated to obtain the daily average count for each site. Species accumulation curve was plotted using the number of species against the sample effort (days).

The relative abundance (R) of waterbirds was calculated using the expression:

$R=\frac{N i}{T n} * 100$

where

$\mathrm{Ni}=$ total number of individuals of the $i$ th species

$\mathrm{Tn}=$ total number of individuals of all species 
Species similarities between the four sites were estimated using the quantitative Morisita-Horn index $\left(\mathrm{C}_{\mathrm{MH}}\right)$. This index is little biased by differences in species richness and sample size (Magurran 1988). This index is derived by the expression:

$\mathrm{C}_{\mathrm{MH}}=\frac{2 \sum(\mathrm{ani} * \mathrm{bni})}{(\mathrm{da}+\mathrm{db}) *(\mathrm{aN} * \mathrm{bN})}$

[Eqn 2]

where

$\mathrm{aN}, \mathrm{bN}=$ total number of individuals in sites $\mathrm{A}$ and $\mathrm{B}$

ani, bni $=$ number of individuals in the $i$ th species in sites $\mathrm{A}$ and $\mathrm{B}$

$\mathrm{da}=\sum \frac{\mathrm{ani}^{2}}{\mathrm{aN}^{2}}$

$\mathrm{db}=\sum \frac{\mathrm{bni}^{2}}{\mathrm{bN}^{2}}$

The value for the similarity indices ranges between zero (0) and one (1), with zero implying no species overlap, 1 = complete overlap, $<0.25=$ similarity is very low, 0.25 $0.50=$ similarity is moderate, $0.50-0.75=$ similarity is high and $>0.75=$ similarity is very high .

The data were subjected to Shapiro-Wilk tests of normality. As the data were not normally distributed, a non-parametric test, Mann-Whitney U test, was used to test for the existence of significant difference in the abundance of waterbirds at the various study sites between the wet and the dry seasons. Mann-Whitney U test was used because few constraints apply to this test (Nachar 2008) and it is one of the most robust non-parametric test (Landers 1981), as it is at less risk to give a wrongly significant result when there is presence of one or two extreme values in the sample under study (Siegel \& Castellan 1988). Also, Kruskal-Wallis test was used to test for the existence of any significant difference in the abundance of waterbirds among the four study sites.

Yearly data on tourist arrival at Mole National Park for the years 1988-2012 were analysed for trend using linear regression and the results presented using a line graph. Also monthly data on arrival of tourists for the years 2012 and 2015 were presented using bar graphs.

\section{Results \\ Species richness}

Overall, 29 species of waterbirds belonging to six orders and 12 families were recorded. Out of these, 18 species were recorded in the wet season compared to 29 species in the dry season (Tables 1 and 2). Considering the migratory status of the species of waterbirds identified in the Mole National Park, 9 out of the 18 species recorded in the wet season were residents, four were intra-African and the remaining five were Palearctic migrants (Table 1). However, in the dry season 12 resident species, eight intra-African migrant and nine Palearctic migrants were recorded (Table 2).

The species accumulation curve showing how the species were discovered throughout the entire study period of 66 days is shown in Figure 2. At the end of the wet season (30 sample days), 18 species of waterbirds were recorded. The last species (29th species) for the entire study period was recorded on the 55th day of sampling. Although sampling continued till the 66th day, the species accumulation curve did not reach asymptotes at the end of the sampling period indicating the possibility of encountering additional species

TABLE 1: Species diversity and relative abundance of waterbirds in the wet season at Mole National Park.

\begin{tabular}{|c|c|c|c|c|c|c|c|c|}
\hline Species & Scientific name & $\begin{array}{l}\text { Migratory } \\
\text { status } \dagger\end{array}$ & Dam 1 and 2 & Lana & Asibey & Haraba & Total & $\begin{array}{l}\text { Relative } \\
\text { abundance }\end{array}$ \\
\hline African-wattled Lapwing & Vanellus senegallus & IM & 43 & - & - & - & 43 & 6.7 \\
\hline African Jacana & Actophilornis africanus & $\mathrm{R}$ & 32 & 42 & 27 & 1 & 101 & 15.6 \\
\hline White-faced Whistling Duck & Dendrocygna viduata & $\mathrm{R}$ & 134 & 44 & & 45 & 223 & 34.5 \\
\hline Hadada Ibis & Bostrychia hagedash & $\mathrm{R}$ & 33 & 7 & 23 & 15 & 78 & 12.1 \\
\hline Senegal Thick-knee & Burhinus senegalensis & IM & 49 & - & - & - & 49 & 7.6 \\
\hline Green-backed Heron & Butorides striata & $\mathrm{R}$ & 22 & 9 & 10 & 4 & 45 & 7.0 \\
\hline Hamerkop & Scopus umbretta & $\mathrm{R}$ & 17 & - & 3 & 1 & 21 & 3.3 \\
\hline Black Crake & Amaurornis flavirostra & $\mathrm{R}$ & 19 & 17 & - & 11 & 46 & 7.1 \\
\hline Wolly-necked Stork & Ciconia episcopus & R & 10 & - & - & - & 10 & 1.5 \\
\hline Little Egret & Egretta garzetta & PM & 1 & - & - & - & 1 & 0.2 \\
\hline Grey Heron & Ardea cinerea & PM & 9 & 4 & 1 & 1 & 15 & 2.3 \\
\hline Saddle-billed Stork & Ephippiorhynchus senegalensis & $\mathrm{IM}$ & 5 & - & - & - & 5 & 0.8 \\
\hline Green Sandpiper & Tringa ochropus & PM & 1 & - & - & - & 1 & 0.2 \\
\hline Black-headed Heron & Ardea melanocephala & $\mathrm{R}$ & 3 & - & - & - & 3 & 0.5 \\
\hline Squacco Heron & Ardeola ralloides & PM & 1 & - & - & - & 1 & 0.2 \\
\hline Purple Heron & Ardea purpurea & PM & - & 2 & - & - & 2 & 0.3 \\
\hline Spur-winged Goose & Plectropterus gambensis & R & 1 & - & - & - & 1 & 0.2 \\
\hline Spur-winged Lapwing & Vanellus spinosus & IM & 1 & - & - & - & 1 & 0.2 \\
\hline $\begin{array}{l}\text { Total number of individuals } \\
\text { encountered }\end{array}$ & & & 381 & 123 & 64 & 78 & 646 & 100.0 \\
\hline Total number of species & & & 17 & 6 & 5 & 7 & 17 & - \\
\hline
\end{tabular}

$\uparrow$, Total number of species: $R=9 ; \quad I M=4 ; P M=5$.

$R$, resident; IM, intra-African migrant; PM, Palearctic migrant. 
TABLE 2: Species diversity and relative abundance of waterbirds in the dry season at Mole National Park.

\begin{tabular}{|c|c|c|c|c|c|c|c|c|}
\hline Common name & Scientific name & $\begin{array}{c}\text { Migratory } \\
\text { status } \dagger\end{array}$ & Dam 1 and 2 & Lana & Asibey & Haraba & Total & $\begin{array}{c}\text { Relative } \\
\text { abundance }\end{array}$ \\
\hline Abdim's Stork & Ciconia abdimii & $\mathrm{IM}$ & - & 10 & 14 & 74 & 98 & 2.4 \\
\hline African Jacana & Actophilornis africanus & $\mathrm{R}$ & 49 & 80 & 25 & 19 & 173 & 4.3 \\
\hline African-wattled Lapwing & Vanellus senegallus & IM & 56 & 17 & 10 & 16 & 99 & 2.5 \\
\hline Black Crake & Amaurornis flavirostra & $\mathrm{R}$ & 27 & - & - & 43 & 70 & 1.7 \\
\hline Black-crowned Night Heron & Nycticorax nycticorax & $\mathrm{R}$ & 22 & - & - & 29 & 51 & 1.3 \\
\hline Black-headed Heron & Ardea melanocephala & $\mathrm{R}$ & 5 & - & 9 & 8 & 22 & 0.5 \\
\hline Cattle Egret & Bubulcus ibis & $\mathrm{IM} / \mathrm{R}$ & 75 & 107 & 43 & 72 & 297 & 7.4 \\
\hline Common Sandpiper & Actitis hypoleucos & PM & 10 & 8 & 2 & 6 & 26 & 0.6 \\
\hline Forbes' Plover & Charadrius forbesi & PM & - & 4 & - & 12 & 16 & 0.4 \\
\hline Greater Painted Snipe & Rostratula benghalensis & $\mathrm{IM}$ & - & - & - & 5 & 5 & 0.1 \\
\hline Green-backed Heron & Butorides striata & $\mathrm{R}$ & 18 & 1 & - & 18 & 37 & 0.9 \\
\hline Green Sandpiper & Tringa ochropus & PM & - & - & 2 & 9 & 11 & 0.3 \\
\hline Grey Heron & Ardea cinerea & PM & 24 & 15 & 15 & 37 & 91 & 2.3 \\
\hline Hamerkop & Scopus umbretta & $\mathrm{R}$ & 24 & 35 & 20 & 75 & 154 & 3.8 \\
\hline Intermediate Egret & Egretta intermedia & $\mathrm{PM} / \mathrm{IM}$ & - & 9 & 2 & 50 & 61 & 1.5 \\
\hline Little Egret & Egretta garzetta & PM & - & - & - & 23 & 23 & 0.6 \\
\hline Long-tailed Cormorant & Phalacrocorax africanus & $\mathrm{R}$ & - & 3 & - & - & 3 & 0.1 \\
\hline Marabou Stork & Leptoptilos crumeniferus & IM & - & 1 & 5 & 6 & 12 & 0.3 \\
\hline Purple Heron & Ardea purpurea & PM & 2 & 11 & 4 & 8 & 25 & 0.6 \\
\hline Saddle-billed Stork & Ephippiorhynchus senegalensis & IM & 1 & 5 & - & 1 & 7 & 0.2 \\
\hline Senegal Thick-knee & Burhinus senegalensis & $\mathrm{IM}$ & 253 & - & - & 24 & 277 & 6.9 \\
\hline Spur-winged Goose & Plectropterus gambensis & R & - & 57 & - & - & 57 & 1.4 \\
\hline Spur-winged Lapwing & Vanellus spinosus: & IM & 4 & 19 & - & - & 23 & 0.6 \\
\hline Squacco Heron & Ardeola ralloides & PM & 45 & 6 & 9 & 13 & 73 & 1.8 \\
\hline White-backed Night Heron & Gorsachius leuconotus & $\mathrm{R}$ & - & - & - & 1 & 1 & 0.0 \\
\hline White-faced Whistling Duck & Dendrocygna viduata & $\mathrm{R}$ & - & 1830 & 82 & - & 1912 & 47.6 \\
\hline Wolly-necked Stork & Ciconia episcopus & $\mathrm{R}$ & 14 & 31 & 24 & 60 & 129 & 3.2 \\
\hline Total number of species & & & 17 & 21 & 17 & 25 & 29 & - \\
\hline
\end{tabular}

$\dagger$, Total number of species: $\mathrm{R}=12 ; \mathrm{IM}=8 ; \mathrm{PM}=9$.

$\mathrm{R}$, resident; IM, intra-African migrant; PM, Palearctic migrant.

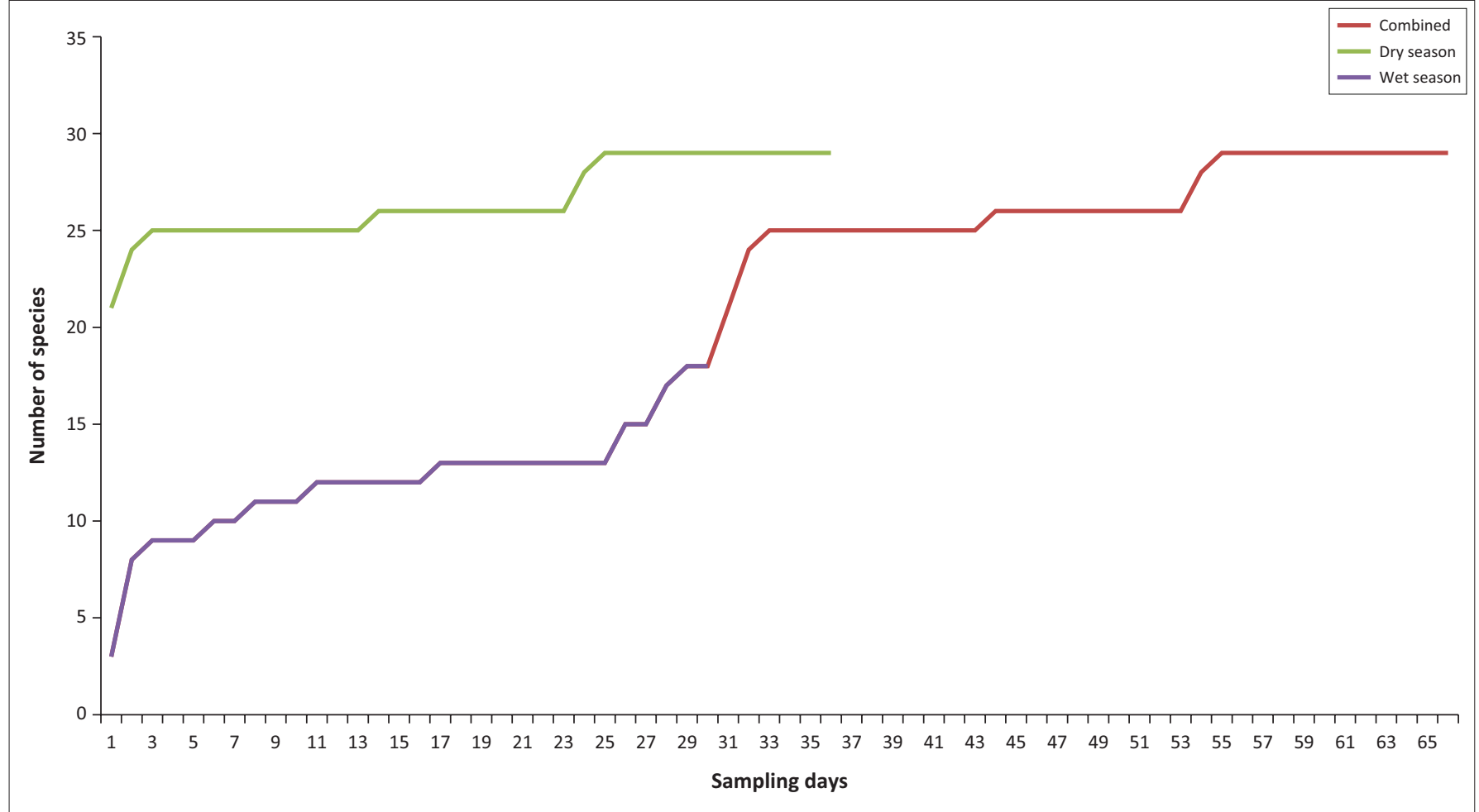

FIGURE 2: Species accumulation curve with a logarithmic regression equation for waterbirds at Mole National Park. 
TABLE 3: Species similarity among the four study sites in Mole National Park, as shown by the quantitative Morisita-Horn index $\left(\mathrm{C}_{\mathrm{MH}}\right)$.

\begin{tabular}{lccc}
\hline Sites & Lana Pool & Haraba Pool & Asibey Pool \\
\hline Dam 1 and 2 & 0.299 & 0.523 & 0.564 \\
Lana Pool & - & 0.209 & 0.494 \\
Haraba Pool & - & - & 0.651 \\
\hline
\end{tabular}

$\mathrm{C}_{\mathrm{MH}^{\prime}}, 2 \cdot \sum$ (ani $*$ bni)/(da+db). aN $* b N$, where $d a=\sum a i^{2} / a N^{2} a n d d b=\sum b n i^{2} / b N^{2}$.

TABLE 4: Mann-Whitney $U$ test of significance difference in seasonal abundance of waterbirds at the four study sites.

\begin{tabular}{|c|c|c|c|c|c|c|}
\hline \multirow[t]{2}{*}{ Sites } & \multicolumn{2}{|c|}{ Wet season } & \multicolumn{2}{|l|}{ Dry season } & \multirow{2}{*}{$\begin{array}{c}\text { Mann- } \\
\text { Whitney U }\end{array}$} & \multirow[t]{2}{*}{$p$} \\
\hline & Mean $\pm S D$ & $N$ & Mean $\pm S D$ & $N$ & & \\
\hline Dam 1 and 2 & $42.20 \pm 14.41^{\mathrm{a}}$ & 9 & $81.20 \pm 14.41^{b}$ & 9 & 2.0 & 0.001 \\
\hline Lana Pool & $20.91 \pm 7.71^{\mathrm{a}}$ & 6 & $257.71 \pm 273.66^{b}$ & 9 & 0.0 & 0.001 \\
\hline Haraba Pool & $12.80 \pm 3.26^{\mathrm{a}}$ & 6 & $70.73 \pm 42.71^{b}$ & 9 & 0.0 & 0.001 \\
\hline Asibey Pool & $6.66 \pm 0.99^{\mathrm{a}}$ & 9 & $32.00 \pm 14.34^{b}$ & 9 & 0.0 & $<0.001$ \\
\hline All sites & $21.40 \pm 16.96^{a}$ & 30 & $110.41 \pm 159.41^{b}$ & 36 & 107.0 & $<0.001$ \\
\hline
\end{tabular}

Note: Mean with similar letters in rows is not significantly different.

$\mathrm{SD}$, standard deviation.

with extended sampling effort. However, the logarithmic regression equation shows that our species accumulation curve is about $84 \%\left(R^{2}=0.8444\right)$ accurate in estimating the species richness in the wet season, $75 \%\left(R^{2}=0.7532\right)$ in the dry season and $80 \%\left(R^{2}=8078\right)$ in the combined wet and dry seasons.

Out of the 29 species of waterbirds encountered, 16 were common to all the four study sites. Pairwise analysis of the wetlands indicated the highest number of shared species (20) to occur between Lana Pool and Haraba Pool and the least (14) between Dam 1 and 2 Wetland and Asibey Pool. Quantitative Morisita-Horn similarity index $\left(\mathrm{C}_{\mathrm{MH}}\right)$ was highest between Haraba Pool and Asibey Pool $\left(\mathrm{C}_{\mathrm{MH}}=0.651\right)$ indicating high similarity and low complementarity. In contrast, $\mathrm{C}_{\mathrm{MH}}$ was lowest between Lana Pool and Haraba Pool $\left(\mathrm{C}_{\mathrm{MH}}=0.209\right)$ (Table 3$)$ indicating very low similarity and very high complementarity.

Out of the 18 species of waterbirds recorded in the wet season, 17 occurred in Dam 1 and 2 Wetland, each of Lana and Haraba Pools recorded seven species followed by five species in Asibey Pool. In contrast, Haraba Pool recorded the highest number of species (25) in the dry season followed by Lana Pool (21) with each of Dam 1 and 2 Wetland and Asibey Pool recording 17 species. Thus, in the dry season, each of Haraba, Lana and Asibey Pools recorded more than $100 \%$ increase in the number of species they recorded in the wet season, whilst Dam 1 and 2 Wetland recorded the same number of species in both seasons.

\section{Species abundance}

A total of 646 waterbirds were encountered during the wet season compared to 4014 in the dry season. In general, there was a significant difference in the abundance of waterbirds between the dry and wet seasons with the dry season recording a significant higher number $(110.41 \pm 159.41)$ of waterbirds than the wet season $(21.40 \pm 16.96)$ (Table 4). Further, pairwise comparison of the mean waterbird abundance in the wet season with that of the dry season indicated a statistically significant abundance of waterbirds with the dry season recording the highest numbers than the wet season on each of the four wetlands (Mann-Whitney U; $p<0.01$ ) (Table 4).

Based on the use of the individual wetlands by the waterbird species, the White-faced Whistling Duck was the most abundant species at three of the study sites, namely Dam 1 and 2 Wetland, Lana and Haraba Pools during the wet season, whilst Asibey Pool was dominated by the African Jacana Actophilornis africanus. In the dry season however, White-faced Whistling Duck again dominated Lana and Asibey Pools, whilst Senegal Thick-knee and Hamerkop, respectively, dominated Dam 1 and 2 Wetland and Haraba Pool. It was also observed that all the Whitefaced Whistling Ducks gathered at Lana Pool towards the end of December 2015 and moved out of the park in early January 2016.

\section{Tourist arrival at Mole National Park}

Figure 3 shows the yearly arrival of tourists (both domestic and foreign) at Mole National Park from the year 1988 to 2012. The linear regression analysis shows an increasing trend in the data. This is an indication that the number of tourists that visit the park increase yearly.

The monthly arrival of domestic tourists at Mole National Park for the year 2012 shows that the peak periods of the arrival of domestic tourists were from June to September (wet season) with September recording the highest numbers. A similar trend exists for foreign tourist arrival with peak period in July and August (wet season) and the highest numbers recorded in July (Figure 4).

The peak arrival periods for foreign tourists at Mole National Park in 2015 were from October to December with December recording the highest. However, a similar trend existed for domestic tourists, except that March recorded extremely high numbers (Figure 5).

\section{Discussion}

Mundava et al. (2012) identified seasonal weather change as a factor that influences the ecology of species, hence the waterbirds species diversity and abundance. This study at Mole National Park recorded higher number of species of waterbirds in the dry season (29) as compared to the wet season (18 species). Also, at all the study sites, the number of species recorded in the dry season was higher than the number recorded in the wet season.

The higher number of waterbird species recorded in the dry season could be because of the gathering of waterbirds at larger permanent waterbodies when the small water bodies dry out (Mundava et al. 2012). Thus, the relatively low number of waterbird species observed during the wet season could be attributed to the dispersal of waterbirds throughout the park to take advantage of the abundance of water all over 


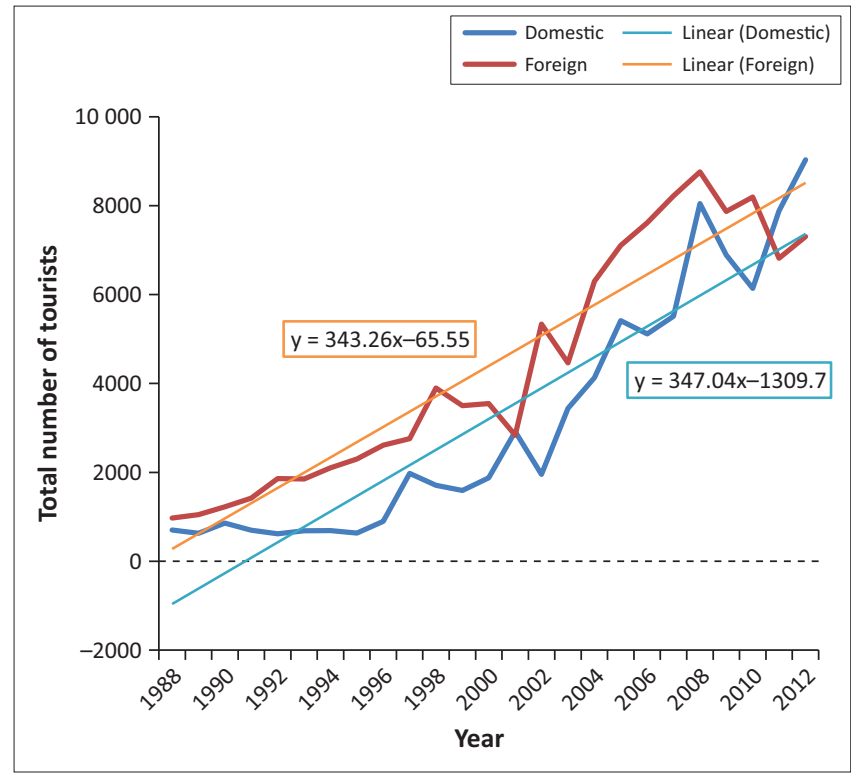

FIGURE 3: Tourist arrival at Mole National Park from 1988 to 2012.

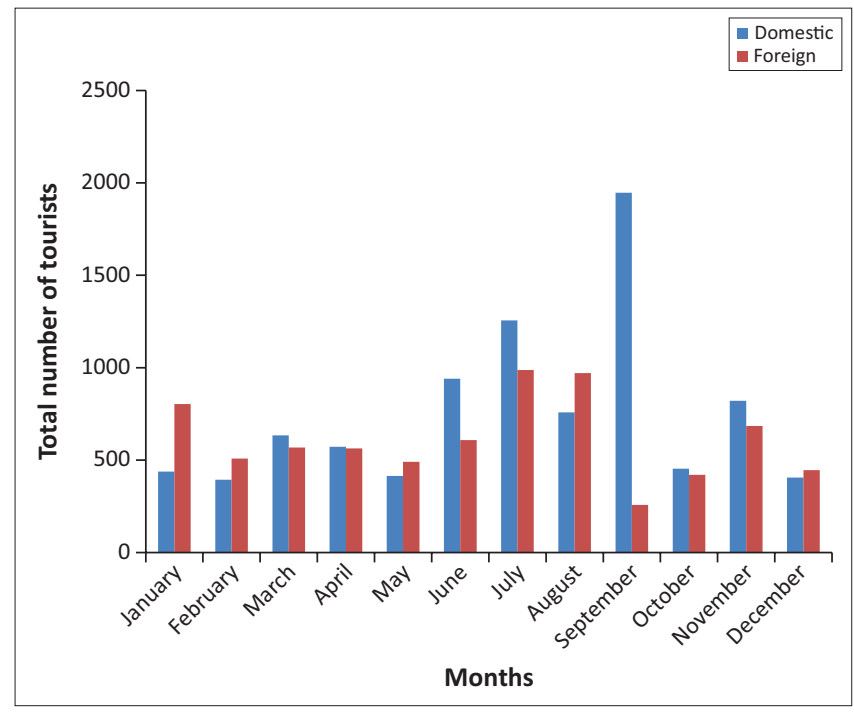

FIGURE 4: Monthly tourist arrivals at Mole National Park in the year 2012.

the park during the wet season as previously observed by Dowsett-Lemaire and Dowsett (2005) and Mundava et al. (2012). Similar observations have been made across Africa including Aynalem and Bekele (2008) who recorded more species of birds in the dry season as compared to the wet season at the southern tip of Lake Tana, Ethiopia.

Some waterbird species can migrate in response to seasonal changes. In this study, migratory birds constituted $50 \%$ of the species recorded in the wet season (nine species) and approximately $59 \%$ of the species recorded in the dry season. The majority of the migratory birds that use Mole National Park are Palearctic migrants. The arrival of more migratory bird species in the dry season in Mole National Park explains why there are more species in the dry season as compared to the wet season. The dry season in Mole National Park coincides with winter, and therefore, more migratory birds spend their winter periods in Mole National Park. This finding also means that Mole National Park is an important

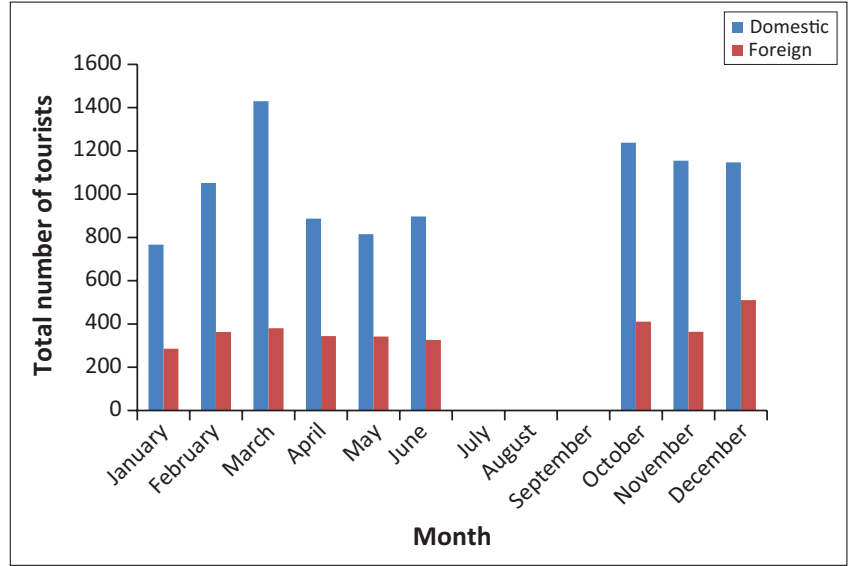

FIGURE 5: Monthly tourist arrivals at Mole National Park in the year 2015.

site for migratory bird species as more than $50 \%$ of its waterbird species are migratory species. Similar findings have been reported by Rajashekara and Venkatesha (2014) who recorded higher numbers of waterbird species in winter as compared to other seasons because of the arrival of migratory waterbirds.

Contrary to the general trend observed in most of the study sites in which higher species richness was recorded in the dry season, the number of species recorded in Dam 1 and 2 Wetland was higher in the wet season. It appears that habitat conditions are better in the wet season as compared to the dry season at Dam 1 and 2 Wetland. This trend could also be attributed to the higher tourist activities at this study site during the dry season because of its easy accessibility (Aikins et al. 2018). High levels of human disturbances have been reported to have a negative impact on waterbird community composition (Ntongani \& Andrew 2013; Rajashekara \& Venkatesha 2014).

The changes in the physical and chemical factors of the hydrosphere are known to affect the ecosystem integrity of wetlands. These abiotic factors in turn affect communities that are dependent on wetlands and also the ecosystem attributes like species richness, density and distribution (Burkert et al. 2004). In this study, with regard to waterbird abundance, a significantly higher number of waterbirds were encountered in the dry season as compared to the wet season. The significant higher numbers of waterbirds observed in the dry season could be attributed to the congregation of waterbirds at larger permanent water bodies when the small water bodies dry out in the dry season and also the easy accessibility to predators in these waterbodies as the waterbodies become shallow (Mundava et al. 2012). According to Dowsett-Lemaire and Dowsett (2005), higher numbers of waterbirds have been reported in the dry season at Mole National Park.

The tourist arrival data for Mole National Park from 1988 to 2012 shows an increasing trend. This implies that tourist numbers will continue to increase yearly. Similarly, Lawer et al. (2013) forecasted the annual patronage by domestic and foreign tourists to Mole National Park. The authors projected 
that the number of visitors to the park will increase in the subsequent years. Furthermore, Ghana Statistical Service (2017) reported that visitor arrivals to Mole National Park increased from 12300 in 2005 to 13500 in 2014, at 1\% average annual growth rate.

Kuuder et al. (2013) reported that although the majority of the ecotourists in Mole National Park are interested in seeing elephants, birdwatchers also frequent the park with about $41 \%$ of the park visitors expressing interest in birds. Our findings also established that more species and higher numbers of waterbirds are found in the dry season as compared to the wet season. However, the analysis of the monthly arrivals of tourists for 2012 shows that the peak period of arrival of both domestic and foreign tourists falls in the wet season. A similar trend existed for the 2015 monthly arrivals. This implies that the majority of the birdwatchers who arrive at Mole National Park miss a lot of species because they arrive in the wet season. This also implies that the majority of the birdwatchers who visit Mole National Park are likely to miss out on most of the migratory birds because the majority (59\%) of the birds in the dry season constituted migratory birds.

\section{Conclusion}

Species richness and abundance of waterbirds in Mole National Park varied according to the wet and dry seasons with both the number of species and abundance higher in the dry season than the wet season. More migratory species are available in the dry season as compared to the wet season. Tourist numbers at Mole National Park continues to increase yearly and the peak period of arrival of tourists is in the wet season. It is therefore indicative that most birdwatchers who visit the park miss out on a number of species and numbers of waterbirds. We recommend that tourists who are interested in waterbirds should particularly visit the park in the dry season as their chances of encountering more species and higher numbers of waterbirds are higher in the dry season as compared to the wet season.

\section{Acknowledgements}

The authors thank the logistics support by Idea Wild. They are also grateful to the Wildlife Division of the Forestry Commission for granting them the permit to undertake this research and the management of Mole National Park for providing the needed support during the data collection.

\section{Competing interests}

The authors declare that they have no financial or personal relationships that may have inappropriately influenced them in writing this article.

\section{Authors' contributions}

T.K.A. conceptualised the research, collected and analysed the data, wrote the original manuscript draft and prepared the manuscript for submission. F.G. and E.H.O. conceptualised the research, advised on data collection and analysis of data and wrote the original and final drafts. All authors provided equal input to the manuscript.

\section{Funding information}

Funds for this research were provided by the University of Ghana-Carnegie Next Generation of Academics in Africa Project.

\section{References}

Aikins, T.K., Gbogbo, F. \& Owusu, E.H., 2018, 'An evaluation of the level of human disturbance to waterbirds at Mole National Park in Ghana', Wetlands Ecology and Management 1-11. https://doi.org/10.1007/s11273-018-9602-2

Aikins, T.K., Ziblim, A.I. \& Tuga, A., 2017, 'A Whinchat Saxicola rubetra ringed in France, recovered in Africa', Malimbus 39, 27-28.

Aynalem, S. \& Bekele, A., 2008, 'Species composition, relative abundance and distribution of bird fauna of riverine and wetland habitats of Infranz and Yiganda at southern tip of Lake Tana, Ethiopia', Tropical Ecology 49(2), 199-209.

Behrouzi-Rad, B., 2009, 'Waterbird populations during dry and wet years in the Hamoun Wetlands Complex, Iran/Afghanistan Border', Podoces 4(2), 88-99.

Bibby, C.J., Burgess N.D., Hill D.A. \& Mustoe, S.H., 2000, Bird census techniques, Academic Press, London, p. 302.

Borrow, N. \& Demey, R., 2010, Field guide to the birds of Ghana, Christopher Helm Publishers, London.

Briggs, P.J., 2007, Ghana, 4th Bradt Travel Guide, Bradt Travel Guides. ISBN 1-84162-205-2.

Burkert, U., Ginzel, G., Babenzien, H.D. \& Koschel, R., 2004, 'The hydrogeology of a catchment area and an artificially divided dystrophic lake consequences for the limnology of Lake Fuchskuhle', Biogeochemistry 71, 225-246. https://doi. org/10.1007/s10533-004-8132-6

Dowsett-Lemaire, F. \& Dowsett, R.J., 2005, Ornithological Surveys in Mole Nationa Park, (August - September 2004 \& March 2005), WDSP Report No. 50-n.

Gbogbo, F., Acheampong, G.K., Atiemo, J.M.Y. \& Crepindale, Q.E., 2013, 'Habitat use pattern of three species of egrets in a small coastal lagoon in Ghana', Ostrich:
Journal of African Ornithology 84(3), 213-217. https://doi.org/10.2989/0030652 Journal of African

Gbogbo, F. \& Attuquayefio, D.K., 2010, 'Issues arising from changes in water bird population estimates in coastal Ghana', Journal of Bird Populations 10, 79-87.

Gbogbo, F., Yeboah, D.O. \& Billah, M.K., 2014, 'Distribution and forage potential of some insect taxa sampled with sweep nets in the flood plains of a Coastal Ramsar Site in Ghana', Open Journal of Ecology 4, 135-144. https://doi.org/10.4236/ oje.2014.43015

Ghana Statistical Service, 2017, Report on the trends in the Tourism Market in Ghana2005-2014, 2nd edn., viewed from http://www.statsghana.gov.gh/docfiles/ publications/Tourism\%20Market $\% 20$ Trends\%20Report $\% 20 \mathrm{in} \% 20$ Ghana.pdf

Greig-Smith, P.W., 1976, 'The composition and habitat preferences of the avifauna of Mole National Park, Ghana', Bulletin of Nigerian Ornithological Society 12, 49-66.

Greig-Smith, P.W., 1977, 'Bird migration at Mole National Park, Ghana', Bulletin of Nigerian Ornithological Society 13, 3-14.

Kuuder, C.W., 2012, 'Tourism potentials of Mole National Park in Northern Ghana', African Journal of Hospitality, Tourism and Leisure 2(1), 1-19.

Kuuder, C.W., Bagson, E. \& Aalangdong, I.O., 2013, 'Assessment of visitor satisfaction in Mole National Park, Ghana', African Journal of Hospitality, Tourism and Leisure 2(3), 1-11.

Landers, J., 1981, Quantification in history, Topic 4: Hypothesis Testing II-Differing Central Tendency, All Souls College, Oxford.

Lawer, E.A., Nasiru, S. \& Kuuder, C.J.W., 2013, 'Forecasting annual patronage by domestic and foreign tourists to Mole National Park, Ghana', American Journal of Tourism Management 2(2), 55-61.

Magurran, A.E., 1988, Ecological diversity and its measurements, Princeton University Press, Princeton, NJ.

Mundava, J., Caron, A., Gaidet, N., Couto, F.M., Couto, J.T., de Garine-Wichatitsky, M. et al., 2012, 'Factors influencing long-term and seasonal waterbird abundance and composition at two adjacent lakes in Zimbabwe', Ostrich 83(2), 69-77. https://doi.org/10.2989/00306525.2012.692726

Nachar, N., 2008, 'The Mann Whitney U: A test for assessing whether two independent samples come from the same distribution', Tutorials in Quantitative Methods for Psychology 4(1), 13-20

Naugle, D.E., Johnson, R.R., Estey, M.E. \& Higgins K.F., 2001, 'A landscape approach to conserving wetland bird habitat in the prairie pothole region of Eastern South Dakota', Wetlands 21(1), 1-17. https://doi.org/10.1672/0277-5212(2001)021 [0001:ALATCW]2.0.CO;2

Nsor, C.A. \& Obodai, E.A., 2014, 'Environmental determinants influencing seasonal variations of bird diversity and abundance in Wetlands, Northern Region (Ghana)', Annals of Experimental Biology 2(3), 17-30. https://doi.org/10.1155/ 2014/548401 
Ntiamoa-Baidu, Y., Nyame, S.K. \& Nuoh, A.A., 2000, 'Trends in the use of a smal coastal lagoon by waterbirds: Muni Lagoon (Ghana)', Biodiversity \& Conservation 9(4), 527-539. https://doi.org/10.1023/A:1008959915039

Ntiamoa-Baidu, Y., Owusu, E.H., Daramani, D.T. \& Nuoh, A.A., 2001, 'Ghana', in L.D.C. Fishpool \& M.I. Evans (eds.), Important bird areas in Africa and associated islands, pp. 367-389, Pisces \& BirdLife Int, Cambridge, UK.

Ntiamoa-Baidu, Y., Piersma, T., Wiersma, P., Poot, M., Battley, P. \& Gordon, C., 1998 'Habitat selection, daily foraging routines and diet of Waterbirds in Coastal Lagoons in Ghana', Ibis 140, 89-103. https://doi.org/10.1111/j.1474-919X.1998. tb04545.x

Ntongani, W.A. \& Andrew, S.M., 2013, 'Bird species composition and diversity in habitats with different disturbance histories at Kilombero Wetland, Tanzania', Open Journal of Ecology 3(7), 482-488. https://doi.org/10.4236/oje.2013. Open
37056
Obodai, E.A. \& Nsor, C.A., 2009, 'Aspects of biodiversity and fish production in the Kukobila wetland in the Savelugu-Nanton District of the Northern Region of Ghana', Ethiopian Journal of Environmental Studies and Management 2(3), 27-35. https://doi.org/10.4314/ejesm.v2i3.48266

Rajashekara, S. \& Venkatesha, M.G., 2014, 'Eco-spatial and temporal variation in waterbirds composition and their relationship with habitat characteristics of Urban Lakes of Bengaluru city, India', International Journal of Advanced Research 2(7), 60-80.

Riffell, S.K., Keas, B.E. \& Burton, T.M., 2001, 'Area and habitat relationships of birds in great lakes coastal wet meadows', Wetlands 21(4), 492-507. https://doi. org/10.1672/0277-5212(2001)021[0492:AAHROB]2.0.CO;2

Riley, W. \& Riley, L., 2005, Nature's strongholds: The world's great wildlife reserves, Princeton University Press, Princeton, NJ.

Siegel, S. \& Castellan, N.J.Jr., 1988, Non parametric statistics for the behavioral sciences, 2nd edn., McGraw-Hill Book Company, New York. 